\title{
Electrophoretic Deposition of YSZ Particles on Non-Conducting Porous NiO-YSZ Substrates for Solid Oxide Fuel Cell Applications
}

\author{
Laxmidhar Besra, ${ }^{\dagger \dagger}$ Charles Compson, and Meilin Liu \\ School of Materials Science and Engineering, Georgia Institute of Technology, Atlanta, Georgia 30332-0245
}

\begin{abstract}
This paper reports a method of performing electrophoretic deposition (EPD) on non-conducting substrates overcoming the requirement of a conducting substrate through the use of porous substrates. The conductivity of the substrate is therefore no longer a limiting factor in the application of EPD. This method is applicable to the fabrication of thick or thin layers of ceramic or metal for various applications. As an example, thin and dense yttria-stabilized zirconia (YSZ) layers have been deposited on a non-conducting NiO-YSZ substrate by EPD from a non-aqueous suspension. A solid oxide fuel cell constructed on these sintered bilayers exhibited power densities of 384 and $611 \mathrm{~mW} / \mathrm{cm}^{2}$ at $750^{\circ}$ and $850^{\circ} \mathrm{C}$, respectively.
\end{abstract}

\section{Introduction}

Solid oxide fuel cells (SOFCs) with high energy conversion Sefficiency and great fuel adaptability have emerged as a new clean electric power generation system. ${ }^{1,2}$ A single SOFC cell comprises a solid electrolyte layer with a cathode on one side and an anode on the other side. Both electrodes are required to be porous for transport of reactants and products through them, while the electrolyte must be dense to prevent leakage of gas and shorting between the two electrodes. ${ }^{1}$ Although a great deal of research is being conducted to develop electrolytes ${ }^{3-5}$ for operation at lower temperatures, yttria-stabilized zirconia (YSZ) and porous cermets of $\mathrm{Ni}-\mathrm{YSZ}$ are by far the most popularly used electrolyte and anode materials, respectively, for SOFC today. The most common starting material for preparation of SOFC anode is a layer of a porous $\mathrm{NiO}-\mathrm{YSZ}$ pellet, which also forms the substrate for deposition of thin and dense YSZ electrolytes. $\mathrm{The} \mathrm{NiO}$ in the pellet becomes reduced to metallic Ni when exposed to fuel, leaving behind the desired porosity suitable for transport of reactant and product gases.

Numerous different techniques have been used for deposition of thin and dense electrolyte films on anode supports, ${ }^{6}$ including physical vapor deposition (PVD) such as sputtering, pulsed laser deposition and molecular beam epitaxy (MBE), ${ }^{7}$ chemical vapor deposition (CVD) or electrochemical vapor deposition methods (EVD), ${ }^{8,9}$ combustion chemical vapor deposition (CCVD), ${ }^{10}$ and plasma technologies. ${ }^{11,12}$ However, the PVD and CVD deposition methods ordinarily require sophisticated and expensive equipment, making them either undesirable or impracticable for implementation in manufacturing processes. They are also plagued by high processing temperatures and limitations on the materials from which the support anode is made.

Electrophoretic deposition (EPD), a cost-effective fabrication method, offers many advantages such as simple apparatus, short

R. Cutler-contributing editor

Manuscript No. 20720. Received June 29, 2005; approved February 2, 2006.

This work was supported by the NASA URETI on UAPT program and the U.S Department of Energy SECA Core Technology Program (under Award Number DE-FC2602NT41572).

${ }^{\dagger}$ Author to whom correspondence should be addressed. e-mail: ldbesra $@$ rrlbhu.res.in ${ }^{\ddagger}$ Present address: Regional Research Laboratory (CSIR), Bhubaneswar 751013, Orissa, deposition time, little restriction in the shape of deposition substrate, suitability for mass production, suitability for deposition of laminates, and no requirement for binder burnout because the green coating contains little or no organics. In an EPD process, charged powder particles dispersed in a liquid medium are attracted and deposited onto a conductive and oppositely charge electrode on application of a DC electric field. The EPD technique has been used successfully for many applications, including biomedical materials, ${ }^{13,14}$ luminescent materials, ${ }^{15-17}$ gas diffusion electrodes, ${ }^{18}$ oxidation-resistant coatings, ${ }^{19}$ multilayer composites, ${ }^{20}$ oxide nano-rods, ${ }^{21}$ carbon nanotube films, ${ }^{22}$ functionally graded ceramics, ${ }^{23,24}$ layered ceramics, ${ }^{25}$ superconductors, ${ }^{26}$ piezoelectric materials, ${ }^{27}$ thick film of silica, ${ }^{28}$ and nano-size zeolite membrane. ${ }^{29}$ Recently, there have also been many attempts to use EPD for SOFC fabrication. ${ }^{30-42}$ To date, however, these studies have used electrically conducting substrates for deposition of YSZ films by EPD. In some instances, the deposition substrate has been subjected to heat treatments in reducing atmospheres ${ }^{42}$ or sputtering of a conducting coating such as platinum ${ }^{43}$ to make it electrically conductive before EPD. Such preparatory steps, however, make the EPD process more expensive. To our knowledge, there are very few reports on direct EPD on non-conducting substrates in the literature. Very recently, Matsuda et $a l^{44}$ used a thin layer of graphite coating on one side of the non-conducting NiO-YSZ porous substrate before EPD. The YSZ films were deposited on the reverse side, which did not contain the graphite layer. But no explanation was offered on the mechanism responsible for EPD on a non-conducting substrate. Recently, we reported EPD of YSZ films on NiO-YSZ substrates, which were previously deposited electrophoretically on thin disks of carbon sheets. ${ }^{45}$ The NiOYSZ deposit, along with the carbon sheet substrate, was transferred into a YSZ bath, followed by constant-voltage EPD for deposition of YSZ. The deposition of YSZ was possible only when the NiO-YSZ substrate was saturated with a solvent. No deposition was possible on completely dried substrates. The carbon sheet becomes burnt off during the subsequent sintering stage, leaving behind a porous $\mathrm{NiO}-\mathrm{YSZ}$ with a thin and dense YSZ layer on it.

In this paper, we report a unique method for EPD of thin and dense YSZ films on a non-conducting NiO-YSZ substrate for SOFC applications. The novelty of the process lies in the fact that it does not necessitate the need for any heat treatment under a reducing atmosphere or use of a conductive substrate/coating. The deposition has been made possible simply through the use of adequately porous substrates to ensure the presence of a conducting solvent path during EPD. Possible mechanisms for deposition on porous substrates have also been proposed.

\section{Experimental Procedure}

\section{(1) Preparation of Porous NiO-YSZ Substrates}

Porous NiO-YSZ substrates used for EPD were formed via tape casting. Commercial NiO powder (Alfa Aesar, Ward Hill, MA) containing a maximum particle size of $10 \mu \mathrm{m}$ was too large to disperse stably in a slurry for tape casting and therefore was milled with $6 \mathrm{~mm}$ diameter YSZ balls as the milling media in 


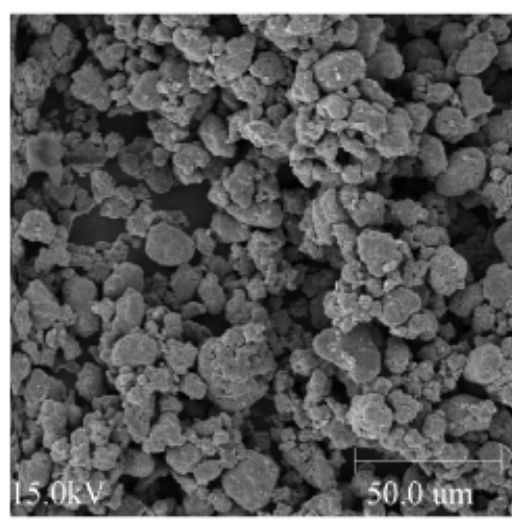

(a) As-received

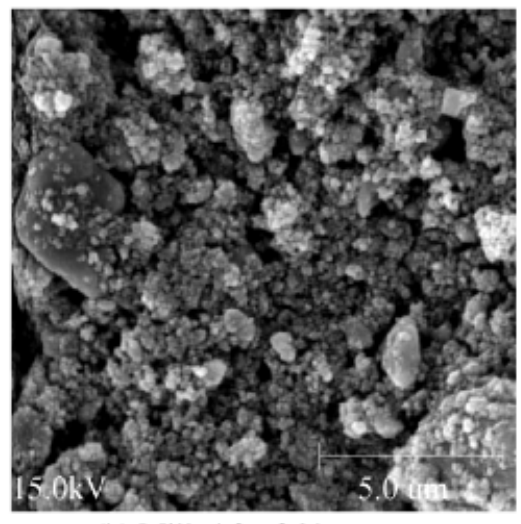

(b) Milled for 96 hours

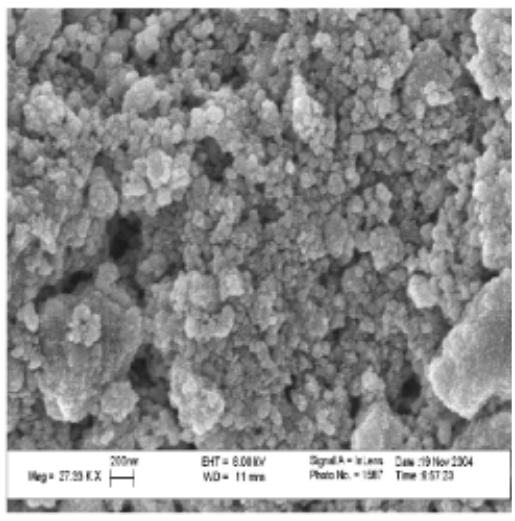

(c) Milled for 240 hours

Fig. 1. SEM images showing the particle size of $\mathrm{NiO}$ powder (a) as received, (b) milled for $96 \mathrm{~h}$, and (c) milled for $240 \mathrm{~h}$.

ethanol for $96 \mathrm{~h}$. Milling yielded much smaller particle sizes than the as-received powders as shown in Fig. 1.

The milled $\mathrm{NiO}$ powder was then dried, ground to separate agglomerates, and mixed with YSZ powder. The YSZ powder (Daiichi Corporation, Fort Lee, NJ, $8 \mathrm{~mol} \%$ ) with a median particle size of $0.26 \mu \mathrm{m}$ was dried at $120^{\circ} \mathrm{C}$ for $48 \mathrm{~h}$ before use to ensure removal of constituent hydroxyl groups from the surface. $\mathrm{NiO}$ and YSZ powders were mixed in a stoichiometric ratio that would produce a 1:1 volume ratio of $\mathrm{Ni}$ to YSZ after reduction. The slurry for tape casting was prepared in a two-stage ballmilling process. The mixed powder was first dispersed in a 50:50 mixture of ethanol and xylene using Menhaden Fish oil and then milled for $4 \mathrm{~h}$ with $6 \mathrm{~mm}$ diameter YSZ balls as milling media to prepare a slurry of $17.3 \mathrm{vol} \%$ (or $65 \mathrm{wt} \%$ ) solids loading. After 4 hours, polyvinyl butyral (PVB) was added as a binder, and two plasticizers, namely polyalkylene glycol (to reduce the binder $T_{\mathrm{g}}$ and control plasticity) and butyl benzyl phthalate (as lubricant and to control plasticity), were added to the slurry and milling was resumed for $24 \mathrm{~h}$.

After de-airing in a vacuum oven at $-5 \mathrm{mmHg}$ for $15 \mathrm{~min}$, to eliminate air entrapped in the suspension during milling, the slurry was cast using a stationary blade $(1.8 \mathrm{~m})$ tabletop caster (Richard E. Mistler Inc., Yardley, PA). The tabletop caster was equipped with a DC motor, variable speed control, a heated casting bed of $1.5 \mathrm{~m}$, a $0.09 \mathrm{~m}^{2}$ granite casting block, and counterdirectional mass-controlled airflow. Casting was performed at a blade height of $150 \mu \mathrm{m}$ and at a rate of $20 \mathrm{~cm} / \mathrm{min}$. The casting chamber atmosphere was controlled using flowing air at a rate of $30 \mathrm{~mL} / \mathrm{min}$ and a heated casting bed set at $26^{\circ} \mathrm{C}$. The temperature and humidity were monitored throughout the duration of casting. After casting was complete, the tape was dried overnight, cut into $13 \mathrm{~mm}$ disks, and fired in air at different temperatures to obtain $\mathrm{NiO}-\mathrm{YSZ}$ substrates of varying porosity. A typical schedule for firing the sample at $1400^{\circ} \mathrm{C}$ is presented in Table I. All NiO-YSZ samples fired from $1100^{\circ}$ to $1400^{\circ} \mathrm{C}$ were held for $5 \mathrm{~h}$ at the peak sintering temperature. The fired samples were weighed, and their diameters and thickness were measured using calipers to estimate density/porosity as presented in Table II. The surface of NiO-YSZ substrate obtained by tape casting was very smooth and of uniform thickness. The density and/or

Table I. Typical Schedule for Sintering the Tape-Cast NiOYSZ Disks at $1400^{\circ} \mathrm{C}$

\begin{tabular}{lcc}
\hline Temperature range $\left({ }^{\circ} \mathrm{C}\right)$ & Ramp rate $\left({ }^{\circ} \mathrm{C} / \mathrm{min}\right)$ & Dwell time $(\mathrm{min})$ \\
\hline RT-200 & 4 & 0 \\
$200-450$ & 1 & 0 \\
$450-1100$ & 4 & 0 \\
$1100-1400$ & 1 & 300 \\
$1400-1100$ & 2 & 0 \\
$1100-$ RT & 4 & 0 \\
\hline
\end{tabular}

$\mathrm{NiO}$, nickel oxide; YSZ, yttria-stabilized zirconia; RT, room temperature. porosity values reported in this paper are an average of five samples with a repetition of five measurements per sample and are confirmed by volume fraction stereology measurements. This ensured in minimizing the error in density/porosity data presented in Table II. The resulting microstructures were analyzed using SEM and are presented in Fig. 2.

\section{(2) EPD of YSZ Films on NiO-YSZ Substrates}

Suspensions of YSZ powder were prepared by dispersing YSZ powder (TZ-8YS, Tosoh, Tokyo, Japan) in acetylacetone (Alfa Aesar, Ward Hill, MA, 99\% purity) under a high-intensity ultrasonic bath in order to break up agglomerates and form a homogeneous and stable colloidal suspension. It was equilibrated for $24 \mathrm{~h}$ and sonicated again for $5 \mathrm{~min}$ before EPD. In contrast to many EPD processes where the suspension requires addition of suitable additives like binders, dispersants, and charging agents, ${ }^{32,46}$ there was no requirement of any additives when using acetylacetone as the solvent. Following our previous communication, ${ }^{45}$ a solid concentration of $10 \mathrm{~g} / \mathrm{L}$ was maintained in all the deposition experiments.

The deposition experiments were conducted using an EPD setup shown schematically in Fig. 3. It consisted of two electrode holders made of Teflon as the principal components. One electrode holder was fixed and the other was movable and could slide along two parallel rods at the bottom so that the distance between the electrodes could be adjusted to a desirable position. Each of the electrode holders had a circular window facing each other to allow the electrodes to be fixed on it. NiO-YSZ substrates were mounted on the fixed holder with a spring contact at the back and served as a cathode, whereas a platinum disk served as the counter-electrode on the movable holder. The spring contact was made from a $0.5 \mathrm{~mm}$ diameter silver wire, the other end of which was directly connected to the negative terminal of the DC power supply unit. The silver and platinum were stable in the acetylacetone solvent and did not undergo any reaction. Unless otherwise mentioned, an electrode spacing of 15 $\mathrm{mm}$ was maintained in all of our EPD experiments. The holders along with the electrodes were immersed in the reservoir containing the suspension of YSZ. Sedimentation of YSZ particles was prevented by mild stirring using a magnetic bead stirrer as

Table II. Relative Density and/or Porosity of NiO-YSZ Substrates Obtained by Tape Casting and Firing at Different Temperatures

\begin{tabular}{lcc}
\hline Temperature $\left({ }^{\circ} \mathrm{C}\right)$ & Relative Density $(\%)$ & Relative Porosity $(\%)$ \\
\hline 1100 & 47.5 & 52.6 \\
1200 & 56.4 & 43.6 \\
1300 & 67.4 & 32.6 \\
1400 & 77.5 & 22.5 \\
\hline
\end{tabular}

$\mathrm{NiO}$, nickel oxide; YSZ, yttria-stabilized zirconia. 
(a)

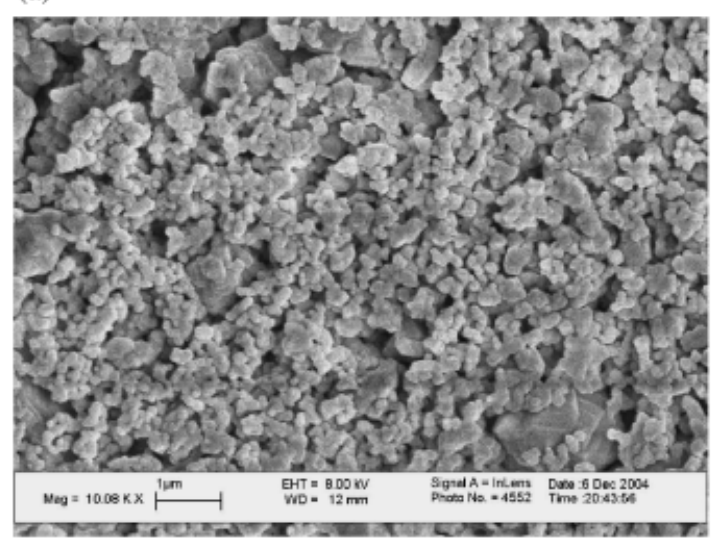

(c)

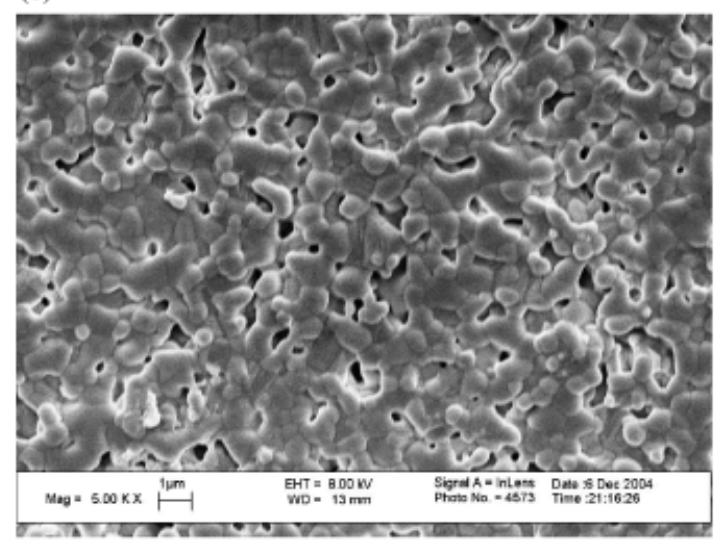

(b)

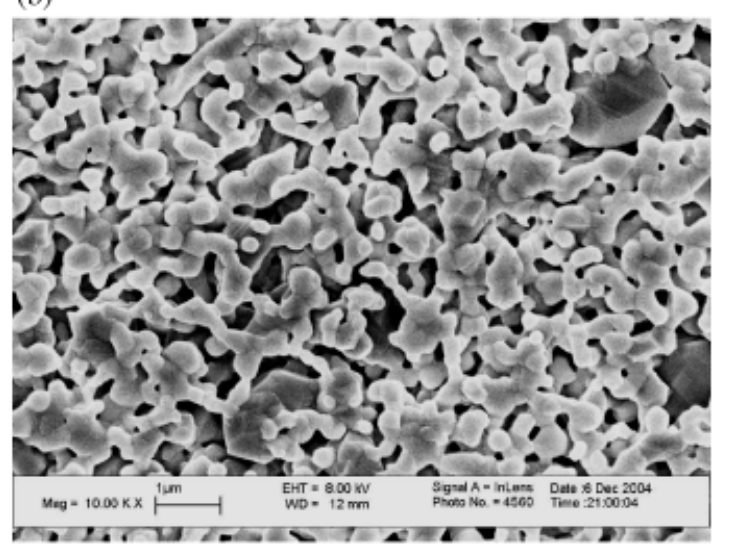

(d)

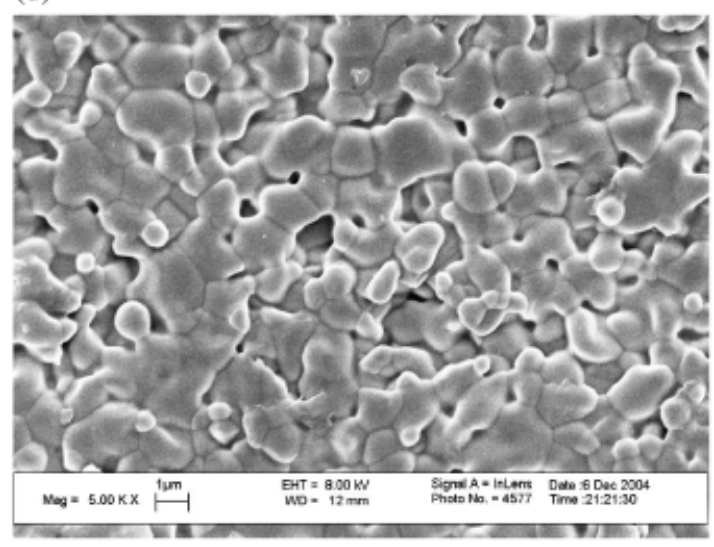

Fig. 2. SEM pictures showing microstructures of NiO-YSZ substrates obtained by tape casting, followed by sintering in air for $5 \mathrm{~h}$ at different temperatures: (a) $1100^{\circ} \mathrm{C}$, (b) $1200^{\circ} \mathrm{C}$, (c) $1300^{\circ} \mathrm{C}$, and (d) $1400^{\circ} \mathrm{C}$. YSZ, yttria-stabilized zirconia.

shown in the figure. EPD experiments were carried out at constant voltages varied in the range from $50 \mathrm{~V}$ to $300 \mathrm{~V}$, using a high-voltage DC power supply unit (Model PS 310, Stanford Research Systems, Sunnyvale, CA) with a deposition time from 1 to 5 min. During deposition, the YSZ particles were attracted and migrated toward the negative electrode (cathode) where they eventually become deposited. Similar cathodic EPD of YSZ from acetylacetone has been reported by several other researchers. ${ }^{32,33,38}$ This indicates that the YSZ particles were positively charged in acetylacetone solvent. The specific surface charge of YSZ in acetylacetone was also measured by a Particle charge detector (Model PCD-03-pH, Mutek GmbH, Herrsching, Germany) and found to be charged positively. The bi-layer consisting of the NiO-YSZ substrate and the deposited YSZ were then sintered in air at $1400^{\circ} \mathrm{C}$ for $4 \mathrm{~h}$.

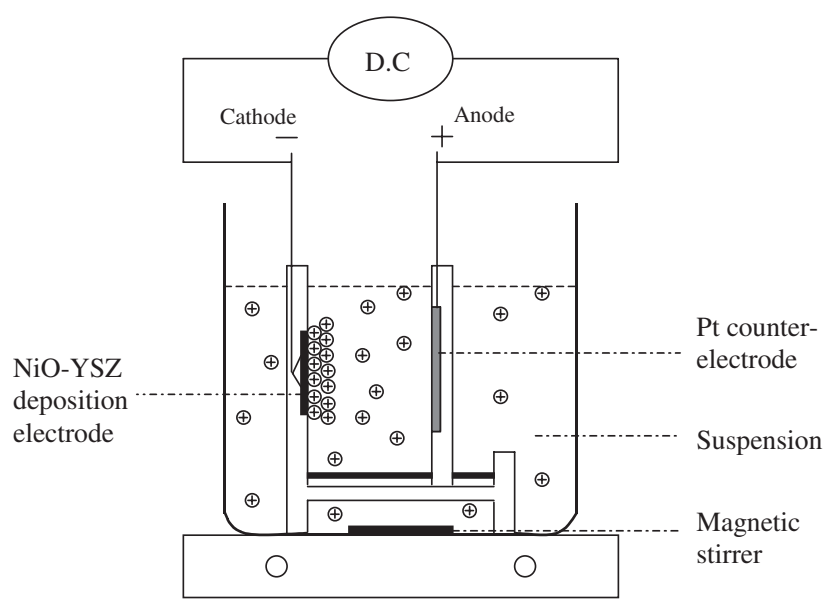

Fig. 3. Schematic diagram of the electrophoretic deposition apparatus.

\section{(3) Fuel Cell Assembly and Testing}

A single fuel cell was constructed on the sintered bi-layer by brush painting a layer of mixed cathode consisting of a 50:50 ratio (by weight) of $\mathrm{La}_{0.8} \mathrm{Sr}_{0.2} \mathrm{MnO}_{3}$ (LSM) and YSZ on the electrolyte, followed by sintering at $1250^{\circ} \mathrm{C}$ for $2 \mathrm{~h}$. The fuel cell was fixed and sealed to an alumina tube using a silver paste (Heraeus, C8710), as described elsewhere. ${ }^{45}$ The seals were cured as the fuel cell was brought to the testing temperature. Hydrogen gas was used as the fuel and ambient air as the oxidant during testing. The cell-tube apparatus was placed in a furnace and brought to the testing temperature with continuous flow of $\mathrm{H}_{2}$ gas. Platinum wires were attached to each electrode as the output terminal and electrical collector. The fuel cell performance was measured with an Solartron Electrochemical Interface (Model SI 1287, Hampshire, UK) interfaced with a computer running Corrware version 2.4a software. The impedance was measured in the frequency range from $100 \mathrm{kHz}$ to 0.1 $\mathrm{Hz}$ using a Solartron HF Frequency response analyzer (Model SI 1255, Hampshire, UK) and the Electrochemical interface connected with a computer running Z-plot version $2.4 \mathrm{a}$ software.

\section{Results and Discussion}

\section{(1) Substrate Characteristics}

The SEM images of the tapecast NiO-YSZ substrates presented in Fig. 2 clearly show densification and a marked change in porosity with increasing firing temperature from $1100^{\circ}-1400^{\circ} \mathrm{C}$. There was a progressive decrease in porosity with increase in firing temperature. A maximum porosity of $52.5 \%$ was obtained for substrates fired at the lowest temperature $\left(1100^{\circ} \mathrm{C}\right)$, whereas the substrate fired at $1400{ }^{\circ} \mathrm{C}$ exhibited a porosity of only $22.4 \%$, as summarized in Table II. 


\section{(2) Deposit Characteristics}

The dispersion of YSZ in acetylacetone solvent was adequate for development of a positive surface charge $(0.532 \mathrm{C} / \mathrm{g})$ on the YSZ particle surface, which facilitated migration of the particles to the oppositely charged cathode and deposition during EPD. Most organic solvents, as also the acetylacetone (Alfa Aesar, $99 \%$ purity) used in the present investigation, are not completely anhydrous. Invariably, some amount of residual water is present in these organic solvents. The development of surface charge is possibly due to the presence of this residual water in the solvent, which is responsible for charging in a manner similar to that in aqueous medium. ${ }^{47}$ The acetylacetone solvents were supplied in glass bottles with airtight caps. Fresh powders and solvents were used to prepare a suspension and were equilibrated in bottles with airtight caps to prevent evaporation loss and change in water content of solvent from day to day. Hence, the deposition of YSZ particles was reproducible between experiments conducted on different days. Figure 4 shows the amount of YSZ deposited on porous $\mathrm{NiO}-\mathrm{YSZ}$ substrates, sintered at temperatures from $1100^{\circ}$ to $1300^{\circ} \mathrm{C}$, as a function of deposition time. It invariably shows rapid deposition rates in the initial period, followed by a decrease with increase in time of deposition. During the initial period of EPD, there is generally a linear relationship between deposition mass and time. In a constant voltage EPD, these trends are expected because while the potential difference between the electrodes is maintained constant, the electric field influencing electrophoresis decreases with deposition time because of the formation of an insulating layer of ceramic particles on the surface of the deposition electrode. It also shows that for a given applied voltage, the density of the deposited layer on substrates of higher porosity (sintered at lower temperatures) is higher than on those of lower porosity (sintered at higher temperatures). In other words, the deposition density increases with substrate porosity. Also, the amount deposited is always proportional to the applied voltage at a given deposition time. This is evident from Fig. 5, which presents the weight of YSZ deposited with increasing applied voltages for a deposition time of $1 \mathrm{~min}$. For each of the three substrates, there is a linear increase in YSZ deposition with increasing potential. The nature of the curves obtained for other deposition times was also similar in the range of applied potentials studied in this investigation.

However, when a dense substrate (pre-fired at $1400^{\circ} \mathrm{C}$ ) was used instead of the porous substrates, no EPD occurred at any applied voltage and/or time of deposition. Similar observations were also reported by Matsuda et al. ${ }^{44}$ This result clearly suggests that the substrate porosity is a key factor in EPD of YSZ films on a non-conductive NiO-YSZ substrate. The electrical conductivity of $8 \mathrm{~mol} \%$ YSZ is reported to be $1 \times 10^{-7} \Omega / \mathrm{cm}$ at $190^{\circ} \mathrm{C}$ and that of $\mathrm{NiO}$ is $5.60 \times 10^{-6} \Omega / \mathrm{cm}$ at $40^{\circ} \mathrm{C}^{48,49}$ This suggests that the composite $\mathrm{NiO}-\mathrm{YSZ}$ substrate is indeed electrically non-conducting in nature. In another communication, ${ }^{50}$ we have shown that for a given applied potential, deposition by

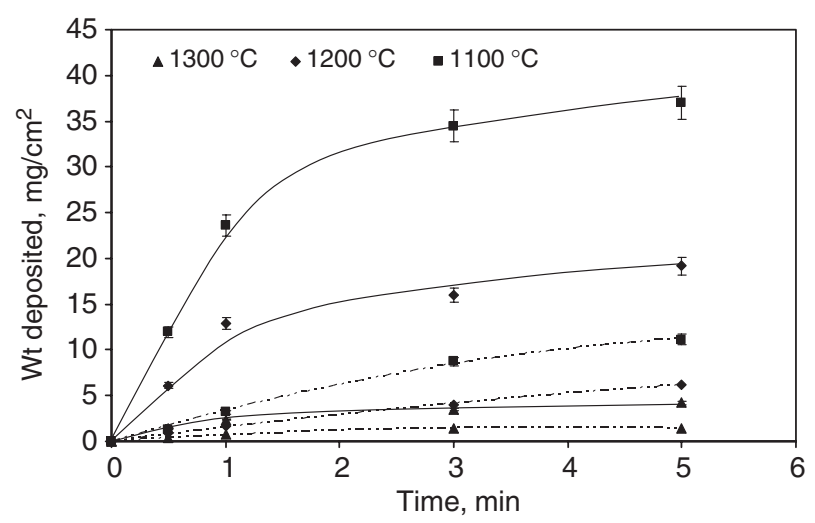

Fig. 4. Deposition characteristics of yttria-stabilized zirconia (YSZ) on porous NiO-YSZ as a function of deposition time for a constant applied voltage of $300 \mathrm{~V}$ (solid lines) and $50 \mathrm{~V}$ (dashed lines).

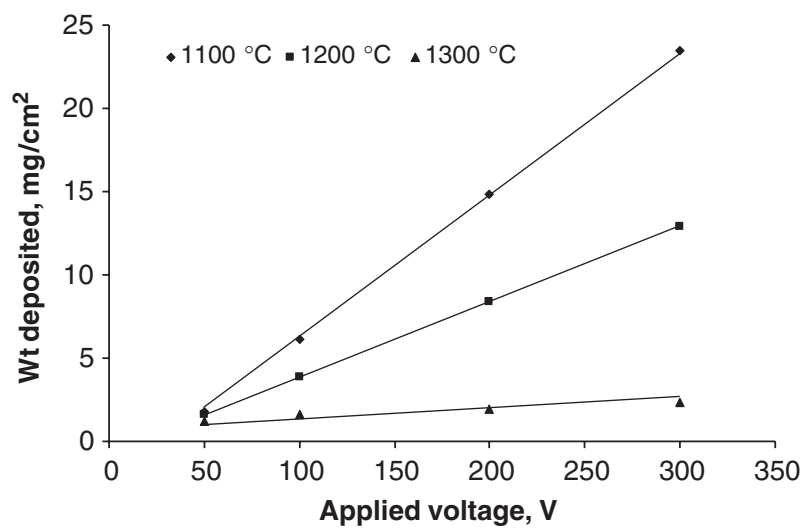

Fig.5. Amount of yttria-stabilized zirconia (YSZ) deposited after 1 $\mathrm{min}$ as a function of applied potential on NiO-YSZ substrates sintered at different temperatures.

EPD occurs only when the substrate porosity exceeds a certain threshold value. The threshold porosity decreases with the magnitude of the applied voltage. The deposit weight increases with increasing substrate porosity. The rate of particle deposition increases more rapidly in the region of lower porosity and tends to plateau above a certain porosity value.

Figure 6 shows the surface and cross-sectional view of sintered YSZ films obtained by a single deposition step. The surface view (Fig. 6(a)) clearly reveals a YSZ film with no cracks. There appear some intra-granular holes on the surface of the YSZ film, but a close examination of the cross section (Fig. 6(b)) reveals that they are isolated and are not continuous in nature. This ensures that the YSZ film is sufficiently dense to prevent gas permeation and would serve as a good electrolyte for SOFC. The thickness of the YSZ film was about $6 \mu \mathrm{m}$. There was good adherence of the electrolyte to the porous NiO-YSZ substrate. There indeed appeared to be strong interconnections between the YSZ grains of the film and the substrate, which is helpful in the transport of oxygen ions from the electrolyte to the anode during the SOFC operation.

\section{(3) Deposition Mechanism}

EPD on conducting substrates has been applied successfully for many applications. Although the exact mechanisms that allow a deposit to be formed are still not entirely clear, ${ }^{51}$ several mechanisms have been suggested. Fukada et al. ${ }^{52}$ give a comprehensive account of the mechanism of deposit formation by EPD. Bouyer and Foissy ${ }^{53}$ suggest that EPD is a two-step process. Under the application of an electric field, the particles in the suspension first migrate to one of the electrodes, depending on the particle charge, where they eventually deposit. The migration step depends on the bulk properties of the colloidal dispersion (bath conductivity, viscosity, particle concentration, size distribution, and surface charge density) and the actual field strength in the bath. Sarkar and Nicholson ${ }^{54}$ inserted a dialysis membrane between the EPD electrodes in an $\mathrm{Al}_{2} \mathrm{O}_{3}$ suspension. The membrane was permeable to ions, but a dense deposit formed thereon and current passed via ionic discharge at the cathode. They concluded that the majority of charge is carried by ions and current passage results therefrom. The deposition step proceeds by a complex superposition of electrochemical and aggregation phenomena. Some of the suggested mechanisms are as follows: (i) flocculation by particle accumulation, ${ }^{55}$ (ii) particle charge-neutralization mechanism, ${ }^{56}$ (iii) electrochemical particle coagulation mechanism, ${ }^{57}$ and (iv) the electrical double-layer distortion and thinning mechanism. ${ }^{54}$ Until recently, the electrical double layer distortion and thinning mechanism had been most widely accepted for EPD on conducting substrates. According to this mechanism, offered by Sarkar and Nicholson, ${ }^{54}$ when the particle lyosphere system (the counter ions from liquid around the charged particle form what is called a 
(a)

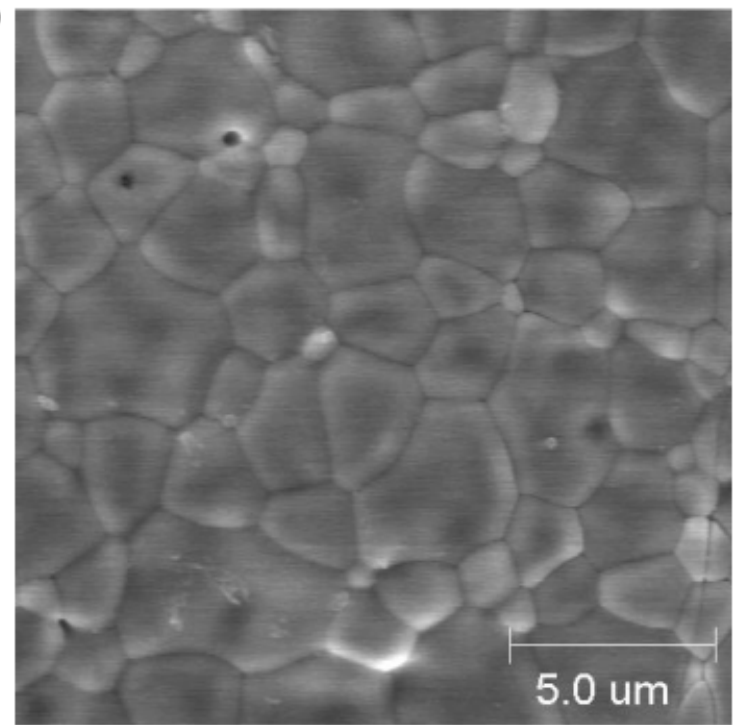

(b)

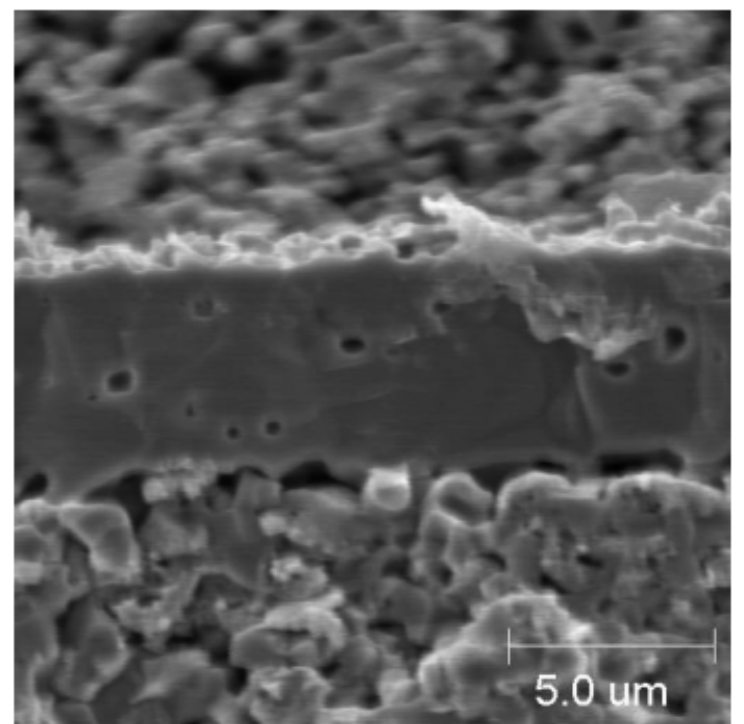

Fig. 6. Typical SEM pictures showing (a) surface and (b) cross-sectional image of a yttria-stabilized zirconia (YSZ) film on a NiO-YSZ substrate (pre-sintered at $1100^{\circ} \mathrm{C}$ for $5 \mathrm{~h}$ ), obtained by constant voltage electrophoretic deposition at $50 \mathrm{~V}$ for $1 \mathrm{~min}$. The deposits were sintered at $1400^{\circ} \mathrm{C}$ for $4 \mathrm{~h}$. The cross-sectional image was taken after SOFC testing with an LSM-YSZ composite cathode layer painted on it. LSM, $\mathrm{La}_{0.8} \mathrm{Sr}_{0.2} \mathrm{MnO}_{3}$.

diffuse double layer or lyosphere) moves, fluid dynamics and applied electric field will distort the double-layer envelope in a manner such that it becomes thinner at the front and wider behind the particle. The cations in the liquid also move to the cathode along with the positively charged particle. The counter ions in the extended "tail" will tend to react with these accompanying cations in high concentrations around them. As a result of such a reaction, the double layer around the "tail" of the particle will also become thin so that the next incoming particle (which has a thin leading double layer) can approach close enough for the London Van der Waals (LVDW) attractive force to dominate and induce coagulation/deposition. The distortion of the double layer leading to coagulation is plausible considering the high concentration of particles near the electrode (or high collision efficiency). Secondly, this mechanism works for incoming particles with thin double-layer heads, coagulating with particles already in the deposit.

When it comes to EPD on non-conducting substrates, however, as in the present case, the mechanisms suggested for conducting substrates do not appear to hold true. The principal concern is how a non-conducting substrate ensures the existence

\section{Spring \\ contact to DC power supply \\ Porous \\ NiO-YSZ \\ substrate \\ Electric field}

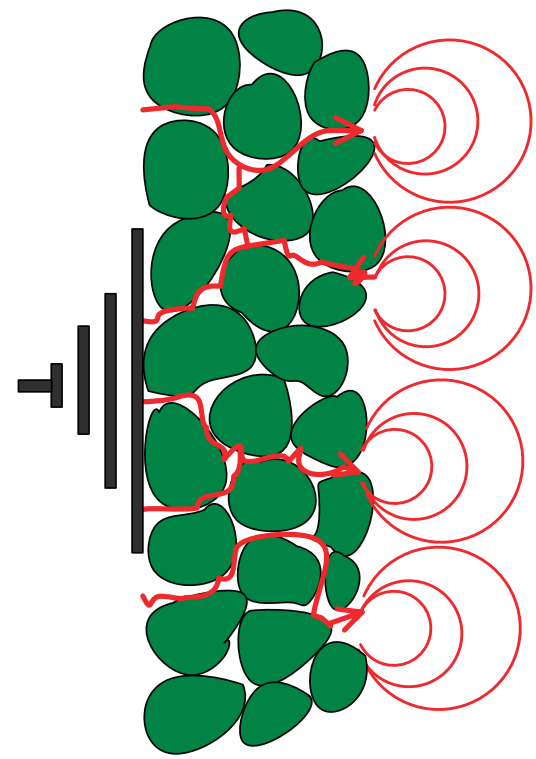

Solvent

Fig. 7. Conceptual representation of the possible electrophoretic deposition mechanism on non-conducting substrates.

of a uniformly distributed electric field in front of it. The presence of an electrically non-conducting substrate will normally tend to block the conducting path from the electrical contact to the particles in suspension. As EPD is based on mobility of the particles upon application of an electric field, deposition would not occur on a non-conducting substrate. In the present case, however, deposition of YSZ on a porous non-conducting $\mathrm{NiO}$ YSZ substrate is indeed possible. We believe that some sort of electrical contact is being developed between the substrate and the particles in the solvent. The best hypothesis is that the current passes through the liquid as shown in Fig. 7. The porous substrates, when saturated with the solvent, allow for development of a "conductive path" between the electrical contact and the particles in suspension. Another possibility of establishment of conductive path by flow of current along the surface of the substrate (rather than through the liquid in the pores) can be ruled out as no deposition occurred on dense substrates at any of the studied applied voltage. The mechanism based on establishment of a conducting path through the porous substrate may also be valid for the previous work by Matsuda et al., ${ }^{44}$ as they also reported no deposition on dense substrates, but did not elaborate on the involved mechanism. It must be noted that the conductive path mechanism depicted in Fig. 7 is an oversimplified illustration showing the manner of establishment of electric field to facilitate EPD. In reality, the incoming YSZ particles deposit not only on the surface of porous NiO-YSZ substrate but they also penetrate the pores leading to continuous closure of the pores with increasing deposition time. In such a scenario, the electrical resistance of the substrate and YSZ film combined together will tend to increase rapidly, leading to a decrease in the rate of deposition. However, it can be expected that deposition, however small, still occurs as long as a conductive path of solvent exists through the combined layer of substrate and deposit.

However, we also foresee that this mechanism of a "conductive path" through a porous substrate by saturation with solvent will be applicable only when the substrate has interconnected porosity. The presence of only closed pores in the substrate will tend to block the "conductive path", preventing any EPD. Although Matsuda et al. ${ }^{44}$ also reported deposition of YSZ on a $\mathrm{NiO}-$ YSZ substrate by EPD, it can be viewed as deposition on a conductive graphite substrate with increased electrical resistance due to the NiO-YSZ layer. For this reason, a relatively high 


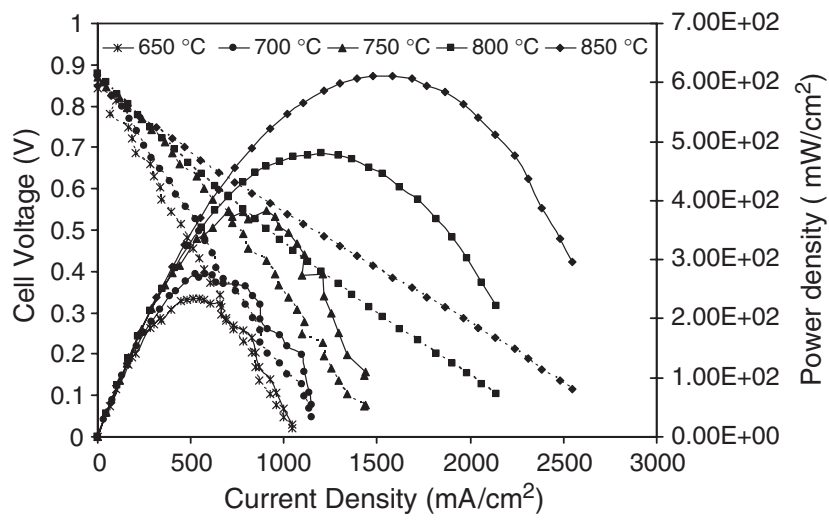

Fig. 8. Performance characteristics of solid oxide fuel cell with a configuration of $\mathrm{NiO}-\mathrm{YSZ} / \mathrm{YSZ} / \mathrm{LSM}-\mathrm{YSZ}$ as a function of operating current density, tested with hydrogen gas as fuel at different temperatures. LSM, $\mathrm{La}_{0.8} \mathrm{Sr}_{0.2} \mathrm{MnO}_{3}$; YSZ, yttria-stabilized zirconia.

deposition voltage of 400-900 V was necessary for EPD. Our method is unique in that we did not coat any graphite or other conducting layer on the substrate, but rather only a spring connected to the DC power supply made contact with substrate. Secondly, our method required a relatively low applied voltage of $50 \mathrm{~V}$ to obtain dense YSZ films of $6 \mu \mathrm{m}$ thickness. Unlike the multiple deposition and sintering steps adopted by other investigators, ${ }^{32,33}$ our approach enabled obtaining dense and gastight films in a single deposition and sintering step. The difference in requirement of applied voltage in this work and that reported by Matsuda et al. ${ }^{44}$ may result from a number of other differences in the experimental conditions adopted. For example, the thickness of the NiO-YSZ substrate used by Matsuda et al. $^{44}$ was $700 \mu \mathrm{m}$, whereas we used substrates of $300 \mu \mathrm{m}$ thickness. The higher thickness of substrate is expected to offer higher electrical resistance. In a similar analogy, such an increase in resistance can also be expected with increasing thickness of the YSZ deposit with time, for which a decrease in deposition rates will occur at a longer deposition time. This is clearly evident from our result presented in Fig. 4. Another possible parameter contributing to voltage requirement during EPD may be the solvent conductivity. A more conductive solvent is expected to require less voltage to transport the YSZ particles, although in the present case, where we are using an organic solvent like acetylacetone, it is believed that such influences will be secondary compared with the effect of substrate thickness.

\section{(4) SOFC Performance}

The performance of an SOFC constructed on sintered bi-layers, tested in $\mathrm{H}_{2}$ at varying temperatures, is shown in Fig. 8. An open-circuit voltage (OCV) of $0.88 \mathrm{~V}$ was obtained at $850^{\circ} \mathrm{C}$, suggesting that the YSZ layer was fairly dense. A peak power density of $611 \mathrm{~mW} / \mathrm{cm}^{2}$ to a corresponding cell voltage of $0.41 \mathrm{~V}$ was obtained at $850^{\circ} \mathrm{C}$. The cell also exhibited a reasonably
Table III. Total Interfacial Resistance of SOFC at Different Operating Temperatures

\begin{tabular}{lcc}
\hline $\begin{array}{l}\text { Temperature } \\
\left({ }^{\circ} \mathrm{C}\right)\end{array}$ & $\begin{array}{c}\text { Electrolyte resistance } \\
\left(\Omega \cdot \mathrm{cm}^{2}\right)\end{array}$ & $\begin{array}{c}\text { Total interfacial resistance } \\
\left(\Omega \cdot \mathrm{cm}^{2}\right)\end{array}$ \\
\hline 650 & 0.256 & 0.56 \\
700 & 0.227 & 0.39 \\
750 & 0.188 & 0.32 \\
800 & 0.154 & 0.30 \\
850 & 0.145 & 0.22 \\
\hline
\end{tabular}

SOFC, solid oxide fuel cell.

good performance at $750^{\circ} \mathrm{C}$, with a power density of $384 \mathrm{~mW} /$ $\mathrm{cm}^{2}$. Such improved performance at an intermediate temperature range is significant as this will help reduce the degradation of cell components, increase flexibility in cell design, and lower manufacturing costs by broadening materials' choices, especially the use of cheap and readily available ferritic steel interconnectors. $^{58,59}$ The performance curves are in concurrence with the impedance data shown in Fig. 9, as measured under the opencircuit condition from $650^{\circ}$ to $850^{\circ} \mathrm{C}$ using a two-electrode configuration. The intercept with a real axis at high frequencies (which is to the left of the $x$-axis) represents the resistance of the electrolyte $\left(R_{\mathrm{b}}\right)$, whereas the diameter of the depressed semicircle corresponds to the total impedance of the two interfaces: the cathode-electrolyte interface $\left(R_{\mathrm{c}}\right)$ and the anode-electrolyte interface $\left(R_{\mathrm{a}}\right)$. Decreasing the total interfacial impedance of an SOFC is an important objective to improve the performance of SOFCs. The total interfacial impedance determined from Fig. 9 is presented in Table III.

\section{Conclusions}

A method for performing EPD on non-conducting substrates has been developed through the use of porous substrates. As an example, EPD of YSZ on a non-conducting and porous $\mathrm{NiO}$ YSZ anode substrate has been demonstrated. We believe that this approach of using porous substrates for EPD on non-conducting substrates can be extended for both thin and thick film deposition on a variety of other non-conducting substrates as well. The success of EPD of YSZ on NiO-YSZ substrates is significant as it enables deposition of thin SOFC electrolytes at a low cost. The SOFC constructed on such bilayers exhibited power densities of $611 \mathrm{~mW} / \mathrm{cm}^{2}$ at $850^{\circ} \mathrm{C}$ and $384 \mathrm{~mW} / \mathrm{cm}^{2}$ at $750^{\circ} \mathrm{C}$. The feasibility of EPD on non-conducting substrates also opens up its use in other applications such as membranes supported on porous substrates for gas separation, sensors, and other electrochemical devices.

\section{Acknowledgment}

One of the authors (L. B.) is grateful to the Department of Science and Technology (DST), Government. of India, for the BOYSCAST fellowship.

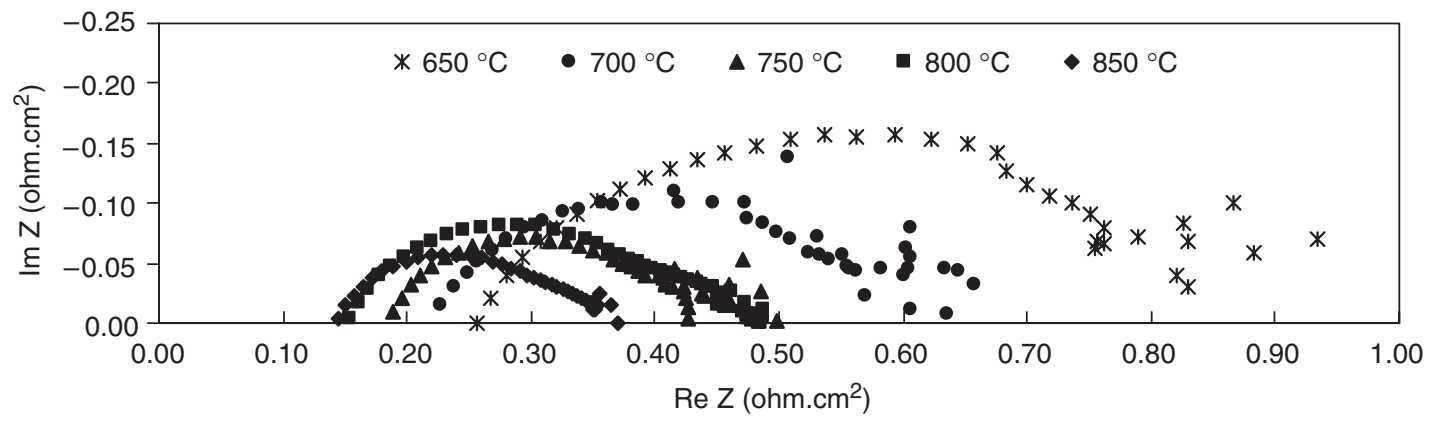

Fig. 9. Typical impedance spectra of a solid oxide fuel cell with a configuration of NiO-YSZ /YSZ/LSM-YSZ under an open-circuit condition using a two-electrode configuration, tested using hydrogen as fuel. LSM, $\mathrm{La}_{0.8} \mathrm{Sr}_{0.2} \mathrm{MnO}_{3} ;$ YSZ, yttria-stabilized zirconia. 


\section{References}

${ }^{1}$ N. Q. Minh and T. Takahashi, Science and Technology of Ceramic Fuel Cells. Elsevier, Amsterdam, the Netherlands, 1995.

${ }^{2}$ A. B. Stambouli and E. Traversa, "Solid Oxide Fuel Cells (SOFCs): A Review of an Environmentally Clean and Efficient Source of Energy," Renew. Sustain. Energy Rev., 6, 433-55 (2002).

${ }^{3}$ B. C. H. Steele and A. Heinzel, "Materials for Fuel Cell Technologies," Nature, 414 [15] 345-52 (2001).

${ }^{4}$ T. Ishihara, M. Honda, T. Shibayama, H. Minami, H. Nishiguchi, and Y. Takita, "Intermediate Temperature Solid Oxide Fuel Cells Using New $\mathrm{LaGaO}_{3}$ Based Oxide Ion Conductor," J. Electrochem. Soc., 145, 3177-83 (1998).

${ }^{5} \mathrm{~S}$. Zha, W. Rauch, and M. Liu, " $\mathrm{Ni}-\mathrm{Ce}_{0.9} \mathrm{Gd}_{0.1} \mathrm{O}_{1.95}$ Anode for GDC Electrolyte-Based Low-Temperature SOFCs," Solid State Ionics, 166, 241-50 (2004).

${ }^{6}$ J. Will, A. Mitterdorfer, C. Kleinlogel, D. Perednis, and L. J. Gauckler, "Fabrication of Thin Electrolytes for Second Generation Solid Oxide Fuel Cells," Solid State Ionics, 131, 79-96 (2000).

X. Chen, N. Wu, and A. Ignatiev, "Thin Film Oxide Fuel Cell and Method for Forming"; US Patent No. 6,645,656 B1, Nov.11, 2003.

${ }^{8}$ U. B. Pal and S. C. Singhal, "Electrochemical Vapour Deposition of Yttria Stabilized Zirconia Films," J. Electrochem. Soc., 137, 2937-41 (1990).

${ }^{9}$ M. Inaba, A. Mineshinge, and T. Maeda, "Growth Rate of Yttria Stabilized Zirconia Thin Films Formed by Electrochemical Vapour Deposition using NiO as an Oxygen Source-II Effect of the Porosity of NiO Substrate," Solid State Ionics, 104 [3-4] 303-10 (1997).

${ }^{10} \mathrm{Z}$. Xu, J. Shankar, and S. Yarmolenko, "Yttria-Stabilised Zirconia Coatings Produced using Combustion Chemical Vapour Deposition," Surf. Coatings Technol., 177, 52-9 (2004).

${ }^{i 1}$ Z. Ogumi, Y. Uchimoto, Y. Tsuji, and Z. Takehara, "Electrodeposition of Thin Yttria-Stabilized Zirconia Layers Using Glow-Discharge Plasma," J. Appl. Phys., 72, 1577-82 (1992).

${ }^{12} \mathrm{H}$. Tsukuda, A. Notomi, and N. Hisatome, "Application of Plasma Spraying to Tubular-Type Solid Oxide Fuel Cells Production," J. Therm. Spray Technol., 9 [3] 364-8 (2000).

${ }^{13}$ M. Wei, A. J. Ruys, B. K. Milthorpe, C. C. Sorrell, and J. H. Evans, "Electrophoretic Deposition of Hydroxyapatite Coatings on Metal Substrate: A NanoParticulate Dual Coating Approach," J. Sol-Gel Sci. Technol., 21, 39-48 (2001).

${ }^{14}$ T. M. Sridhar and U. K. Mudali, "Development of Bioactive Hydroxyapatite Coatings on Type 316L Stainless Steel by Electrophoretic Deposition for Orthopaedic Applications," Trans. Indian Inst. Metals, 56 [3] 221-30 (2003).

${ }^{15}$ J.-H. Yum, S.-Y. Seo, S. Lee, and Y.-E. Sung, " $\mathrm{Y}_{3} \mathrm{Al}_{5} \mathrm{O}_{12}: \mathrm{Ce}_{0.05}$ Phosphor Coating on Gallium Nitride for White Light Emitting Diodes," J. Electrochem. Soc., 150 [2] H47-52 (2003).

${ }^{16}$ M. J. Shane, J. B. Talbot, B. G. Kinney, E. Sluzky, and H. R. Hesse, "Electrophoretic Deposition of Phosphors: II Deposition Experiments and Analysis," $J$. Colloid Interface Sci., 165, 334-40 (1994).

${ }^{17}$ M. J. Shane, J. B. Talbot, R. G. Schreiber, C. L. Ross, E. Sluzky, and K. R. Hesse, "Electrophoretic Deposition of Phosphors: I Conductivity and Zeta Potential Measurements," J. Colloid Interface Sci., 165, 325-33 (1994).

${ }^{18} \mathrm{~K}$. Hayashi and N. Furuya, "Preparation of Gas Diffusion Electrodes by Electrophoretic Deposition," J. Electrochem. Soc., 151 [3] A354-7 (2004)

${ }^{19}$ J. Y. Choudhury, K. N. Rai, and H. S. Ray, "Electrophoretic Deposition of Ceramic Compounds on Metal and Graphite Substrates," Trans. Indian Inst. Metals, 31 [6] 468-9 (1978).

${ }^{20}$ K. Yamashita, E. Yonehara, X. Ding, M. Nagai, T. Umegaki, and M. Matsuda, "Electrophoretic Coating of Multilayered Apatite Composite on Alumina Ceramics," J. Biomed. Mat. Res., 43 [1] 46-53 (1998).

${ }^{21}$ S. J. Limmer and G. Cao, "Sol-Gel Electrophoretic Deposition for the Growth of Oxide Nanorods," Adv. Mater., 15 [5] 427-31 (2003).

${ }^{22} \mathrm{C}$. Du, D. Heldbrant, and N. Pan, "Preparation and Preliminary Property Study of Carbon Nanotubes Films by Electrophoretic Deposition," Mater. Lett., 57, 434-8 (2002).

${ }^{23}$ S. Put, J. Vleugels, G. Anne, and O. Van der Biest, "Functionally Graded Ceramic and Ceramic-Metal Composites Shaped by Electrophoretic Deposition," Colloids Surf. A: Physicochem. Eng. Aspects, 222, 223-32 (2003).

${ }^{24}$ P. Sarkar, S. Datta, and P. S. Nicholson, "Functionally Graded Ceramic/Ceramic and Metal/Ceramic Composites by Electrophoretic Deposition," Composites Part B, 28B, 49-56 (1997).

${ }^{25}$ B. Ferrari, A. J. Sanchez-Herencia, and R. Moreno, "Electrophoretic Forming of $\mathrm{Al}_{2} \mathrm{O}_{3} / \mathrm{Y}$-TZP Layered Ceramics form Aqueous Suspension," Mater. Res. Bull., 33 [3] 487-99 (1998).

${ }^{26}$ S. K. F. Yau and C. C. Sorrel, "High-J $\mathrm{J}_{\mathrm{c}}(\mathrm{Bi}, \mathrm{Pb})_{2} \mathrm{Sr}_{2} \mathrm{Ca}_{2} \mathrm{CuO}_{10+\mathrm{x}}$ Tapes Fabricated by Electrophoretic Deposition," Physica C, 282-287, 2563-4 (1997).

${ }^{27}$ J. Van Tasses and C. A. Randall, "Electrophoretic Deposition and Sintering of thin/thick PZT Film," J. Eur. Ceram. Soc., 19, 955-8 (1999).

${ }^{28} \mathrm{~K}$. Hasegawa, S. Kunugi, M. Tatsumisago, and T. Minami, "Preparation of Thick Films by Electrophoretic Deposition Using Modified Silica Particles Derived by Sol-Gel Method," J. Sol-Gel Sci. Technol., 15, 243-9 (1999).

${ }^{29}$ W. Shan, Y. Zhang, W. Yang, C. Ke, Z. Gao, Y. Ke, and Y. Tang, "Electrophoretic Deposition of Nano-Size Zeolites in Non-Aqueous Medium and its Application in Fabricating Thin Zeolite Membranes," Microporous Mesoporous Mater., 69, 35-42 (2004).

${ }^{30}$ T. Ishihara, K. Sato, Y. Mizuhara, and Y. Takita, "Preparation of Yttria Stabilized Zirconia Films for Solid Oxide Fuel Cells by Electrophoretic Deposition Method," Chem. Lett., 943-6 (1992).

${ }^{31}$ T. Ishihara, K. Shimose, T. Shiomitsu, and Y. Takita, "Electrophoretic Deposition of $\mathrm{Y}_{2} \mathrm{O}_{3}-$ Stabilized $\mathrm{ZrO}_{2}$ on the Porous $\mathrm{La}_{0.8} \mathrm{Sr}_{0.2} \mathrm{MnO}_{3}$ Cathode Substrate for SOFC"; pp. 334-43 in Proceedings of Fourth International Symposium on
Solid Oxide Fuel Cells (SOFC-IV), Edited by M. Dokiya, O. Yamamoto, H. Tagawa, and S. C. Singhal. Electrochemical Society, Pennington, NJ, 1995.

${ }^{32}$ T. Ishihara, K. Sato, and Y. Takita, "Electrophoretic Deposition of $\mathrm{Y}_{2} \mathrm{O}_{3}$ Stabilised $\mathrm{ZrO}_{2}$ Electrolyte Films in Solid Oxide Fuel Cells," J. Am. Ceram. Soc., 79 [4] 913-9 (1996).

${ }^{33}$ T. Ishihara, K. Shimose, T. Kudo, H. Nishiguchi, T. Akbay, and Y. Takita, "Preparation of Yttria-Stabilised Zirconia Thin Films on Strontium-Doped $\mathrm{LaMnO}_{3}$ Cathode Substrate Via Electrophoretic Deposition for Solid Oxide Fuel Cells," J. Am. Ceram. Soc., 83 [8] 1921-7 (2000).

${ }^{34}$ R. N. Basu, C. A. Randall, and M. J. Mayo, "Development of Zirconia Electrolyte Films on Porous Lanthanum Manganite Cathodes by Electrophoretic Deposition"; pp. 303-8 in New Materials for Batteries and Fuel Cells, Vol. 575. Edited by D. H. Doughty, L. F. Nazar, M. Arakawa, H. P. Brack, and K. Naoi. Material Research Society symposium proceedings, San Francisco, USA, 2000

${ }^{35}$ R. N. Basu, M. J. Mayo, and C. A. Randall, "Fabrication of Zirconia Electrolyte Films by Electrophoretic Deposition"; US patent No. 6,270,642 B1, Aug 2001

${ }^{36}$ R. N. Basu, C. A. Randall, and M. J. Mayo, "Fabrication of Dense Zirconia Electrolyte Films for Tubular Solid Oxide Fuel Cells by Electrophoretic Deposition," J. Am. Ceram. Soc., 84 [1] 33-40 (2001).

${ }^{37} \mathrm{Z}$. Peng and M. Liu, "Preparation of Dense Platinum-Yttria Stabilized Zirconia and Yttria Stabilized Zirconia Films on Porous $\mathrm{La}_{0.9} \mathrm{Sr}_{0.1} \mathrm{MnO}_{3}$ (LSM) Substrates," J. Am. Ceram. Soc., 84 [2] 283-8 (2001).

${ }^{38} \mathrm{~F}$. Chen and M. Liu, "Preparation of Yttria Stabilized Zirconia (YSZ) Films on $\mathrm{La}_{0.9} \mathrm{Sr}_{0.1} \mathrm{MnO}_{3}$ (LSM)and LSM-YSZ Substrates Using an Electrophoretic Deposition (EPD) Process," J. Eur. Ceram. Soc., 21, 127-34 (2001).

${ }^{39}$ I. Zhitomirsky and A. Petric, "Electrophoretic Deposition of Ceramic Materials for Fuel Cell Applications," J. Eur. Ceram. Soc., 20, 2055-61 (2000).

${ }^{40}$ I. Zhitomirsky and A. Petric, "Electrophoretic Deposition of Electrolyte Materials for Solid Oxide Fuel Cell," J. Mater. Sci., 39, 825-31 (2004).

${ }^{41}$ M. Matsuda, O. Ohara, K. Murata, S. Ohara, T. Fukui, and M. Miyake, "Electrophoretic Fabrication and Cell Performance of Dense Sr- and Mg-Doped $\mathrm{LaGaO}_{3}$-Based Electrolyte Films," Electrochem. Solid State Lett., 6 [7] A140-3 (2003).

${ }^{42}$ J. Will, M. K. M. Hruschka, L. Gubler, and L. J. Gauckler, "Electrophoretic Deposition of Zirconia on Porous Anodic Substrate," J. Am. Ceram Soc., 84 [2] 328-32 (2001).

${ }^{43}$ J. Van Tassel and C. A. Randall, "Potential for Integration of Electrophoretic Deposition into Electronic Device Manufacture; Demonstrations Using Silver/ Palladium," J. Mater. Sci., 39, 67-879 (2004).

${ }^{44}$ M. Matsuda, T. Hosomi, K. Murata, T. Fukui, and M. Miyake, "Direct EPD of YSZ Electrolyte Film onto Porous NiO-YSZ Composite Substrate for Reduced-Temperature Operating Anode-Supported SOFC," Electrochem. Solid State Lett., 8 [1] A8-11 (2005).

${ }^{45}$ L. Besra, S. Zha, and M. Liu, "Preparation of NiOYSZ/YSZ Bi-Layer for Solid Oxide Fuel Cells by Electrophoretic Deposition," J. Power Sources, (2006) (in press).

${ }^{46}$ T. Mathews, N. Rabu, J. R. Sellar, and B. C. Muddle, "Fabrication of $\mathrm{La}_{1-x}$ $\mathrm{Sr}_{x} \mathrm{Ga}_{1-y} \mathrm{Mg}_{y} \mathrm{O}_{3-(x+y) / 2}$ Thin Films by Electrophoretic Deposition and its Conductivity Measurement," Solid State Ionics, 128, 111-5 (2000).

${ }^{47}$ L. Vandeperre, C. Zhao, and O. Van der Biest, "Correlation Between Surface Charge of a Powder in Water and Electrophoretic Deposition from Non-Aqueous Media, Novel Chemistry and Processing of Ceramics"; pp. 69-74 in Proceedings of the Novel Chemistry/Processing session of the Sixth Conference and Exhibition of the European Ceramic society, Brighton, UK, 20-24 June 1999, Misc: Edited by J. Binner. IOM Communications Ltd, London, 2000.

${ }^{48}$ V. Esposito, D. Z. de Florio, F. C. Fonseca, E. N. S. Muccillo, R. Muccillo, and E. Traversa, "Electrical Properties of YSZ/NiO Composites Prepared by a Liquid Mixture Technique,” J. Eur. Ceram. Soc., 25, 2637-41 (2005).

${ }^{49} \mathrm{~V}$. Biju and M.Abdul Khadar, "DC Conductivity of Consolidated Nanoparticles of NiO," Mater. Res. Bull., 36, 21-33 (2001).

${ }^{50} \mathrm{~L}$. Besra and M. Liu, "YSZ Film on Dry Pressed Non-Conducting NiO-YSZ Substrates for SOFC Application by Electrophoretic Deposition," Materi. Chem. Phys. (submitted).

${ }^{51}$ O. O. Van der Biest and L. J. Vandeperre, "Electrophoretic Deposition of Materials," Аппи. Rev. Mater. Sci., 29, 327-52 (1999).

${ }^{52}$ Y. Fukada, N. Nagarajan, W. Mekky, Y. Bao, H. S. Kim, and P. S. Nicholson, "Electrophoretic Deposition-Mechanisms, Myths and Materials," J. Mater. Sci., 39, 787-801 (2004).

${ }^{53} \mathrm{~F}$. Bouyer and A. Foissy, "Electrophoretic Deposition of Silicon Carbide," $J$. Am. Ceram. Soc., 82 [8] 2001-10 (1999).

${ }^{54}$ P. Sarkar and P. S. Nicholson, "Electrophoretic Deposition (EPD): Mechanisms, Kinetics and Application to Ceramics," J. Am. Ceram. Soc., 79 [8] 1987-2002 (1996).

${ }^{55}$ H. C. Hamaker, "Formation of Deposition by Electrophoresis," Trans. Faraday Soc., 36, 279-83 (1940).

${ }^{56}$ F. Grillon, D. Fayeulle, and M. Jeandin, "Quantitative Image Analysis of Electrophoretic Coatings,” J. Mater. Sci. Lett., 11, 272-5 (1992).

${ }^{57}$ H. Koelmans, "Suspensions in Non-Aqueous Media," Phillips Res. Rep., 10, 161-93 (1995)

${ }^{58}$ B. C. H. Steele, "State of the Art SOFC Ceramic Materials," pp. 375 in Proceedings of 1st European Solid Oxide Fuel Cell Forum, Edited by U. Bossel. European SOFC Forum, Oberrohrdorf, Switzerland, 1994.

${ }^{59}$ H. P. Buckkremer, U. Diekmann, L. G. J. DeHaart, H. Kabs, U. Stimming, and D. Stoever, "Advances in the Anode Supported Planar SOFC Technology," p. 160 in Proceedings of 5th International Symposium on Solid Oxide Fuel Cells (SOFC-V), Edited by V. Stimming, S. C. Singhal, H. Tagawa, and W. Lehnert The Electrochemical Society, Pennington, NJ, 1997. 